\title{
Lactobacillus panis sp. nov., from Sourdough with a Long Fermentation Period
}

\author{
BJÖRN G. WIESE, ${ }^{1}$ WALTER STROHMAR, ${ }^{1}$ FRED A. RAINEY, ${ }^{2}$ AND HANS DIEKMANN ${ }^{1 *}$ \\ Institut für Mikrobiologie der Universität Hannover, Schneiderberg 50, D-30167 Hannover, ${ }^{1}$ \\ and DSMZ-Deutsche Sammlung von Mikroorganismen und Zellkulturen GmbH, \\ 38124 Braunschweig, ${ }^{2}$ Germany
}

\begin{abstract}
Two Lactobacillus strains isolated from rye sourdough most closely resemble Lactobacillus oris on the basis of their physiological, morphological, and chemotaxonomic characteristics. A 16S ribosomal DNA sequence analysis showed that these two strains clustered with, but were separate from, $L$. oris, Lactobacillus vaginalis, and Lactobacillus pontis. The results of DNA-DNA hybridization experiments indicated that the new two isolates represent a new Lactobacillus species, for which we propose the name Lactobacillus panis; strain DSM $6035^{\mathrm{T}}$ is the type strain of this species.
\end{abstract}

The genus Lactobacillus is a well-defined taxon $(9,12)$. A variety of Lactobacillus strains have been isolated from sourdough in the past and have been placed in the species Lactobacillus acidophilus, Lactobacillus delbrueckii, Lactobacillus farciminis (obligately homofermentative), Lactobacillus casei, Lactobacillus homohiochii, Lactobacillus plantanum (facultatively heterofermentative), Lactobacillus brevis, Lactobacillus buchneri, Lactobacillus fermentum, Lactobacillus hilgardii, Lactobacillus sanfrancisco, and Lactobacillus viridescens (obligately heterofermentative) $(9,21,24)$. The predominant taxon in many sourdough batches, $L$. brevis var. lindneri, was reclassified as L. sanfrancisco by Weiss and Schillinger (27). However, modern molecular taxonomic approaches have led to altered species arrangements $(2,8)$, and the taxonomy of the genus Lactobacillus is still under review. A new species, Lactobacillus pontis, was isolated recently from rye sourdough (25).

Traditionally, one-stage processes or processes involving several stages and fermentation times of between 3 and $48 \mathrm{~h}$ are used to manufacture rye sourdough (18). A one-stage process with an exceptionally long souring period of 5 days was developed in 1977 (13), and the microflora involved in this process was investigated by Strohmar and Diekmann (20). However, physiological, morphological, and chemotaxonomic characterization of the Lactobacillus strains isolated did not lead to unambiguous species assignments. In this study two strains from the study of Strohmar and Diekmann (20) were selected for further analysis of their systematic positions. In order to obtain precise identification and phylogenetic placement, the experiments performed previously were repeated and sodium dodecyl sulfate (SDS)-polyacrylamide gel electrophoresis (PAGE) of soluble proteins, 16S ribosomal DNA (rDNA) sequencing, and DNA-DNA-hybridization were also performed.

\section{MATERIALS AND METHODS}

Organisms and growth conditions. The strains were maintained as stab cultures on modified MRS agar, which contained (per liter) $10 \mathrm{~g}$ of bacteriological peptone (Difco), $3 \mathrm{~g}$ of Lab-Lemco Powder (Difco), $5 \mathrm{~g}$ of yeast extract, $4 \mathrm{~g}$ of glucose, $0.4 \mathrm{~g}$ of maltose, $0.5 \mathrm{~g}$ of cysteine, $5 \mathrm{~g}$ of sodium acetate $\cdot 3 \mathrm{H}_{2} \mathrm{O}, 2 \mathrm{~g}$ of citric acid (diammonium salt), $2 \mathrm{~g}$ of $\mathrm{K}_{2} \mathrm{HPO}_{4}, 0.1 \mathrm{~g}$ of $\mathrm{MgSO}_{4} \cdot 7 \mathrm{H}_{2} \mathrm{O}, 0.04 \mathrm{~g}$ of

\footnotetext{
* Corresponding author.
}

$\mathrm{MnSO}_{4} \cdot \mathrm{H}_{2} \mathrm{O}, 1 \mathrm{~g}$ of Tween 80 , and $15 \mathrm{~g}$ of agar. The $\mathrm{pH}$ was adjusted to 6.4 with $32 \% \mathrm{HCl}$. The cultures were incubated for 2 to 3 days at $37^{\circ} \mathrm{C}$. The strains were stored at $4^{\circ} \mathrm{C}$ and were transferred to fresh medium monthly (20). The two isolates obtained (strains $1^{\mathrm{T}}[\mathrm{T}=$ type strain] and 50 [20]) were deposited in the DSMZ-Deutsche Sammlung von Mikroorganismen und Zellkulturen GmbH, Braunschweig, Germany, as strains DSM $6035^{\mathrm{T}}$ and DSM 6036, respectively. The type strains used in comparative analyses were provided by the DSMZ-Deutsche Sammlung von Mikroorganismen und Zellkulturen GmbH. To isolate DNA, cells were grown in MRS-bouillon (Merck) supplemented with $0.5 \mathrm{~g}$ of L-cysteine per liter and $20 \mathrm{mM}$ DL-threonine and were harvested by centrifugation in the late exponential phase.

Physiological characterization. The tests used to determine Gram staining characteristics, cell wall peptidoglycan content, catalase activity, the lactate isomer present, gas production, and arginine hydrolysis were performed by using previously described methods (20). Sugar fermentation patterns were determined by using an API $50 \mathrm{CH}$ system in anaerobic jars.

Isolation of DNA. To isolate DNA, we used a modified Marmur procedure (22). DNA was purified as described previously, except that the last steps of the procedure were modified as follows: crude DNA was incubated with RNase A $(80 \mu \mathrm{g} / \mathrm{ml})$ at $37^{\circ} \mathrm{C}$ for $3 \mathrm{~h}$; then $75 \mu \mathrm{g}$ of proteinase $\mathrm{K}$ per ml was added and the mixture was incubated overnight. After the final precipitation, the DNA was dissolved in sterile double-distilled water. DNA base composition was determined by the high-performance liquid chromatography (HPLC) method (23) by using wild-type lambda phage DNA (Boehringer, Mannheim, Germany) as the standard.

16S rDNA sequencing. Genomic DNA extraction, PCR-mediated amplification of the $16 \mathrm{~S}$ rDNA, and purification of the PCR products were carried out as described previously $(16,17)$. Purified PCR products were sequenced by using a Taq DyeDeoxy terminator cycle sequencing kit (Applied Biosystems, Weitherstadt, Germany) as directed by the manufacturer. Sequence products were electrophoresed by using an Applied Biosystems model 373A DNA sequencer. The $16 S$ rDNA sequences were aligned manually with the sequences of representatives of the genus Lactobacillus.

Pairwise evolutionary distances were computed by using the correction of Jukes and Cantor (11). The least-squares distance method of De Soete (4) was used to construct a phylogenetic dendrogram from distance matrices. Only positions which were unambiguous in all of the strains compared were included in the phylogenetic analysis.

DNA-DNA hybridization. DNA-DNA hybridization rates were determined by obtaining thermal renaturation rates (3) with a Gilford model 2600 spectrophotometer equipped with a Gilford model 2527 thermoprogrammer and a HewlettPackard model $7225 \mathrm{~B}$ plotter. The DNA was dialyzed against $2 \times$ SSC $(1 \times$ SSC is $150 \mathrm{mM} \mathrm{NaCl}$ plus $15 \mathrm{mM}$ sodium citrate), fragmented, and dissolved in $2 \times$ SSC (7) to a final concentration of $50 \mu \mathrm{g} / \mathrm{ml}(10)$. The DNA solutions were heated in cuvettes at 80 to $102^{\circ} \mathrm{C}$ (the temperature was increased $1^{\circ} \mathrm{C} / \mathrm{min}$ ) to denature them and were kept at $102^{\circ} \mathrm{C}$ for $5 \mathrm{~min}$. Then, the DNA was cooled to the optimum renaturation temperature (3) kept at this temperature for 30 to 40 min. The slope of a 20 - to 30 -min interval during the linear renaturation phase was graphically determined from the $A_{260}$ plot and was used to calculate levels of complementarity (percentages of reassociation).

Protein pattern analysis. Soluble cell proteins were extracted and SDS-PAGE was performed as described by Vogel et al. (25). Before the gels were electrophoresed, the protein concentration in each extract was adjusted to $100 \mu \mathrm{g} / \mathrm{ml}$. The gels were stained with silver stain by using the technique described by Blum et al. (1) and were compared visually. 
TABLE 1. Differential characteristics of L. panis, L. oris, L. vaginalis, L. pontis, and L. brevis ${ }^{a}$

\begin{tabular}{|c|c|c|c|c|c|c|}
\hline Characteristic & $\begin{array}{c}\text { L. panis } \\
\text { DSM } 6035^{T}\end{array}$ & $\begin{array}{l}\text { L. panis } \\
\text { DSM } 6036\end{array}$ & $\begin{array}{c}\text { L. oris } \\
\text { DSM } 4864^{\mathrm{T}}\end{array}$ & $\begin{array}{l}\text { L. vaginalis } \\
\text { DSM } 5837^{\mathrm{T}}\end{array}$ & $\begin{array}{c}\text { L. pontis } \\
\text { DSM } 8475^{\mathrm{T} b}\end{array}$ & $\begin{array}{c}\text { L. reuteri } \\
\text { DSM } 20016^{\mathrm{T}}\end{array}$ \\
\hline Peptidoglycan type & Lys-D-Asp & Lys-D-Asp & Lys-D-Asp ${ }^{d}$ & Orn-D-Asp ${ }^{e}$ & Orn-D-Asp & Lys-D-Asp \\
\hline $\mathrm{NH}_{3}$ produced from arginine & $-f$ & - & - & + & + & + \\
\hline Growth at $15^{\circ} \mathrm{C}$ & - & - & - & - & + & - \\
\hline Growth at $45^{\circ} \mathrm{C}$ & + & + & + & + & + & + \\
\hline $\mathrm{G}+\mathrm{C}$ content $(\mathrm{mol} \%)$ & $48.3 \pm 0.3^{g}$ & $48.0 \pm 0.3^{g}$ & $49-51^{d, h}$ & $38-41^{e, h}$ & $53-56^{b g}$ & $40-42^{h}$ \\
\hline \multicolumn{7}{|l|}{ Acid produced from: } \\
\hline$N$-Ácetylglucosamine & - & - & - & - & ND & ND \\
\hline Amygdalin & - & $+(\mathrm{D})$ & + & - & ND & ND \\
\hline L-Arabinose & + & + & + & - & - & + \\
\hline L-Arabitol & - & - & - & - & ND & ND \\
\hline Arbutin & - & $+(\mathrm{D})$ & - & - & ND & ND \\
\hline Gentiobiose & $+(\mathrm{D})$ & $+(\mathrm{D})$ & + & - & ND & ND \\
\hline D-Glucitol & - & $+(\mathrm{D})$ & - & - & - & - \\
\hline Gluconate & + & - & + & - & + & + \\
\hline 2-Ketogluconate & - & - & - & - & ND & ND \\
\hline 5-Ketogluconate & - & - & - & - & ND & ND \\
\hline Lactose & + & + & + & + & - & + \\
\hline D-Mannose & + & + & - & + & - & - \\
\hline Melibiose & + & + & + & + & - & + \\
\hline$\alpha$-Methyl-D-glucoside & + & + & - & - & ND & ND \\
\hline$\beta$-Methyl-D-xyloside & + & + & - & - & - & ND \\
\hline L-Rhamnose & - & - & - & - & ND & - \\
\hline Ribitol & + & - & - & - & ND & ND \\
\hline D-Ribose & + & + & + & - & + & + \\
\hline Salicin & $+(\mathrm{D})$ & + & - & - & - & - \\
\hline Starch & ND & ND & $-^{d}$ & $-{ }^{e}$ & ND & ND \\
\hline D-Turanose & $+(\mathrm{D})$ & $+(\mathrm{D})$ & - & - & ND & ND \\
\hline D-Xylose & + & + & + & - & - & - \\
\hline L-Xylose & + & - & - & - & ND & ND \\
\hline Esculin hydrolyzed & + & + & + & $+(\mathrm{D})$ & - & ND \\
\hline
\end{tabular}

a All strains are gram positive and catalase negative, generate gas from glucose, produce DL-lactate, and utilize fructose, sucrose, and raffinose.

${ }^{b}$ Data from reference 25

${ }^{c}$ Species data from reference 12.

${ }^{d}$ Data from reference 6.

${ }^{e}$ Data from reference 5 .

$f_{-}$, negative reaction; + , positive reaction; + (D), delayed positive reaction; ND, not determined.

${ }^{g}$ Determined by the HPLC method.

${ }^{h}$ Determined by the thermal denaturation method.

Plasmid assay. The plasmid contents of the new strains were determined by using the miniprep method described by O'Sullivan and Klaenhammer (14). For cell lysis, the use of mutanolysin was crucial. Plasmid size was estimated by comparing the relative running distances obtained with the running distances of the plasmids of Lactococcus lactis DSM 4643, which were used as standards. Agarose gels were stained with SYBR Green I (Molecular Probes, Inc., Mo$\mathrm{BiTec}$, Göttingen, Germany) instead of ethidium bromide by following the manufacturer's instructions.

Nucleotide sequence accession numbers. The 16S rDNA sequences of strains DSM $6035^{\mathrm{T}}$ and DSM $4864^{\mathrm{T}}$ have been deposited in the EMBL database under accession numbers $\mathrm{X} 94230$ and $\mathrm{X} 94229$, respectively.

\section{RESULTS}

Chemotaxonomic characterization. The occurrence of arginine hydrolysis and the cell wall peptidoglycan, growth temperatures, and physiological characteristics of the new strains indicated that they are very similar to Lactobacillus oris. This was confirmed by the $\mathrm{G}+\mathrm{C}$ content of the DNA, which was 1 mol\% lower than the value reported for the $L$. oris type strain. However, there were slight differences in the sugar fermentation patterns of the new strains and $L$. oris, and there were also differences between the strains, but these differences alone do not justify establishment of a new species. The characteristics of strains DSM $6035^{\mathrm{T}}$ and DSM 6036 and the species that are most similar chemotaxonomically to these strains are compared in Table 1.
The SDS-PAGE protein patterns revealed that strains DSM $6035^{\mathrm{T}}$ and DSM 6036 were more similar to each other than to the type strains of the species that are most similar chemotaxonomically ( $L$. oris, $L$. vaginalis, $L$. pontis, $L$. reuteri, and $L$. brevis) (Fig. 1).



FIG. 1. SDS-PAGE of the soluble proteins of L. panis DSM $6035^{\mathrm{T}}$ (lane 2) and DSM 6036 (lane 3 ), L. oris DSM $4864^{\mathrm{T}}$ (lane 4), L. vaginalis DSM $5837^{\mathrm{T}}$ (lane 5), $L$. pontis DSM $8475^{\mathrm{T}}$ (lane 6 ), $L$. reuteri DSM $20016^{\mathrm{T}}$ (lane 7 ), and $L$. brevis DSM $20054^{\mathrm{T}}$ (lane 8 ). Lanes 1 and 9 contained size markers. 




FIG. 2. Phylogenetic dendrogram showing the relationship of L. panis DSM $6035^{\mathrm{T}}$ to other Lactobacillus species. Scale bar $=5$ nucleotide substitutions per 100 nucleotides.

Phylogenetic position. We determined the almost complete $16 \mathrm{~S}$ rDNA sequences of strains DSM $6035^{\mathrm{T}}$ and DSM 6036 ( $>95 \%$ of the corresponding Escherichia coli sequence). We also determined the $16 \mathrm{~S}$ rDNA sequence of $L$. oris DSM $4864^{\mathrm{T}}$ because of the high number of ambiguous bases in the original sequence deposited in the EMBL database. Figure 2 shows the phylogenetic position of strain DSM $6035^{\mathrm{T}}$ within the cluster composed of $L$. oris, $L$. vaginalis, $L$. pontis, and $L$. reuteri.

It is clear from both the phylogenetic dendrogram and the $16 \mathrm{~S}$ rDNA similarity values (Table 2) that strain DSM $6035^{\mathrm{T}}$ is most closely related to $L$. oris (level of sequence similarity, $98.3 \%$ ). The $16 \mathrm{~S}$ rDNA sequence of strain DSM 6036 was identical to that of strain DSM $6035^{\mathrm{T}}$. Levels of $16 \mathrm{~S}$ rDNA similarity higher than $97 \%$ were found for strains DSM $6035^{\mathrm{T}}$ and DSM 6036 and for the species L. oris, L. pontis, and $L$. vaginalis.
DNA-DNA hybridization experiments were performed with these organisms. A high level of DNA relatedness $(92 \%)$ was found when we used isolates DSM 6035 ${ }^{\mathrm{T}}$ and DSM 6036. The levels of reassociation with $L$. oris, $L$. pontis, and $L$. vaginalis were lower, ranging from 54 to $34 \%$ (Table 3).

We detected three plasmids (approximate sizes 10, 16, and $40 \mathrm{kbp}$ ) in strain DSM $6035^{\mathrm{T}}$ and no plasmids in strain DSM 6036. L. oris DSM $4864^{\mathrm{T}}$ also contained a $40-\mathrm{kbp}$ plasmid, and Lactobacillus vaginalis DSM $5837^{\mathrm{T}}$ contained a $56-\mathrm{kbp}$ plasmid, while L. pontis DSM $8475^{\mathrm{T}}$ contained four plasmids (7.8, 9, 12, and $13 \mathrm{kbp}$ ).

\section{DISCUSSION}

Our phenotypic characterization of two new Lactobacillus strains indicated that these organisms are most similar to $L$. oris but not identical to this species. When soluble protein patterns were used as additional markers, they confirmed that the new strains were more similar to each other than to any other phenotypically similar type strain. A simple visual comparison was appropriate for this purpose.

According to the recommendations of the Ad Hoc Committee on Reconciliation of Approaches to Bacterial Systematics, the phylogenetic definition of a species includes "strains with approximately $70 \%$ or greater DNA-DNA relatedness" (26). Values of $>70 \%$ are normally found with strains that exhibit levels of $16 \mathrm{~S}$ rDNA similarity of more than $97 \%$ (19). Following these recommendations, after phenotypic characterization we determinated the $16 \mathrm{~S}$ rDNA sequences and calculated the levels of similarity to other species. The next step was to investigate the levels of DNA-DNA relatedness to the species with which the new strains exhibited more than $97 \% 16 \mathrm{~S}$ rDNA similarity. A high level of DNA-DNA relatedness between the two new Lactobacillus isolates, in contrast to only low to moderate levels of relatedness to previously described species, provided evidence that a new species should be established. The DNA-DNA hybridization results are consistent with the 16S rDNA-based dendrogram and the phenotypic characteristics, which show that the most closely related species is $L$. oris.

16S rDNA analysis has been shown to be a useful tool for differentiating Lactobacillus species $(2,15)$. The sequence of

TABLE 2. Levels of $16 \mathrm{~S}$ rDNA similarity for $L$. panis and related Lactobacillus species

\begin{tabular}{|c|c|c|c|c|c|c|c|c|c|c|c|c|}
\hline \multirow[b]{2}{*}{ Species } & \multicolumn{12}{|c|}{$\% 16 \mathrm{~S}$ rDNA similarity } \\
\hline & $\underset{\Xi}{\Xi}$ &  & $\underset{\vdots}{\vdots}$ & 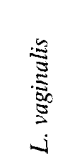 & 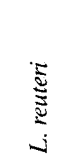 &  & 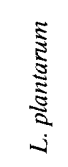 & $\begin{array}{l}3 \\
5 \\
5 \\
5 \\
3\end{array}$ & 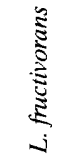 & 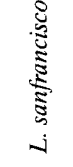 & 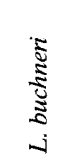 & 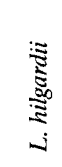 \\
\hline L. oris & 98.3 & & & & & & & & & & & \\
\hline L. pontis & 97.2 & 96.9 & & & & & & & & & & \\
\hline L. vaginalis & 97.7 & 96.9 & 97.3 & & & & & & & & & \\
\hline L. reuteri & 95.7 & 95.8 & 96.5 & 96.7 & & & & & & & & \\
\hline L. fermentum & 92.6 & 92.3 & 93.3 & 92.7 & 94.4 & & & & & & & \\
\hline L. plantarum & 90.3 & 90.0 & 90.9 & 91.0 & 91.0 & 91.4 & & & & & & \\
\hline L. brevis & 90.8 & 90.9 & 91.7 & 91.3 & 91.0 & 91.6 & 93.8 & & & & & \\
\hline L. fructivorans & 91.1 & 91.1 & 91.8 & 91.9 & 91.9 & 91.7 & 92.9 & 93.5 & & & & \\
\hline L. sanfrancisco & 89.5 & 89.6 & 90.1 & 90.0 & 90.0 & 90.5 & 91.9 & 92.2 & 94.4 & & & \\
\hline L. buchneri & 90.8 & 91.0 & 91.5 & 91.5 & 91.3 & 91.1 & 92.3 & 94.2 & 94.2 & 92.5 & & \\
\hline L. hilgardii & 91.7 & 92.0 & 92.0 & 92.4 & 92.0 & 91.3 & 92.9 & 94.2 & 94.5 & 92.6 & 97.3 & \\
\hline L. salivarius & 88.6 & 88.7 & 88.9 & 88.9 & 89.3 & 90.0 & 91.0 & 91.4 & 91.2 & 90.1 & 91.3 & 91.7 \\
\hline
\end{tabular}


TABLE 3. DNA-DNA hybridization results

\begin{tabular}{lccccc}
\hline \multirow{2}{*}{ Strain } & \multicolumn{5}{c}{ \% Reassociation with DNA from: } \\
\cline { 2 - 7 } & DSM & DSM & DSM & DSM & DSM \\
& $6035^{\mathrm{T}}$ & 6036 & $4864^{\mathrm{T}}$ & $8475^{\mathrm{T}}$ & $5837^{\mathrm{T}}$ \\
\hline L. panis DSM 6035 & 100 & & & & \\
L. panis DSM 6036 & $92(3)^{a}$ & 100 & & & \\
L. oris DSM 4864 & $54(5)$ & $46(2)$ & 100 & & \\
L. pontis DSM 8475 & $43(1)$ & $47(1)$ & ND $^{b}$ & 100 & \\
L. vaginalis DSM 5837 & $42(3)$ & $34(3)$ & $42(1)$ & ND & 100 \\
\hline
\end{tabular}

${ }^{a}$ The numbers in parentheses are the numbers of determinations; the maximum difference was $15 \%$.

${ }^{b} \mathrm{ND}$, not determined.

the oligonucleotide probe described as specific for $L$. pontis (25) is also present in the 16S rDNA sequence of Lactobacillus panis DSM $6035^{\mathrm{T}}$ (Table 4). Despite this, the cell wall interpeptides, growth temperature, arginine cleavage, and $\mathrm{G}+\mathrm{C}$ contents of strains DSM $6035^{\mathrm{T}}$ and DSM 6036 are clearly different from those of $L$. pontis. It should be pointed out that as new taxa are discovered and their 16S rDNA sequences are determined, the specificity of previously designed probes may become lower. The differences in cell morphology and sugar fermentation reactions between the two $L$. panis strains may be attributable to the presence of plasmids. On the basis of a combination of phenotypic, chemotaxonomic, and genomic data we propose that strains DSM $6035^{\mathrm{T}}$ and DSM 6036 should be placed in a new Lactobacillus species, L. panis.

Description of Lactobacillus panis Wiese, Strohmar, Rainey, and Diekmann sp. nov. Lactobacillus panis (pa'nis. L. masc. gen. n. panis, of bread). Cells are rod shaped ( 0.7 to 0.9 by 2.5 to $6 \mu \mathrm{m}$ ) and form chains or clusters. Colonies are white to grey, convex, smooth, and up to $2 \mathrm{~mm}$ in diameter. Cells are gram positive. Nonmotile. Grows at 30 and $45^{\circ} \mathrm{C}$ but not at $15^{\circ} \mathrm{C}$. Anaerobic. Catalase negative. Heterofermentative, producing D- and L-lactic acids. Arginine is not hydrolyzed. Acid is produced from L-arabinose, fructose, galactose, glucose, lactose, maltose, $D$-mannose, melibiose, $\alpha$-methyl-D-glucoside, $\beta$ methyl-D-xyloside, raffinose, D-ribose, salicin, sucrose, and Dxylose. Acid is not produced from $N$-acetyl-glucosamine, amidon, D-arabinose, arabitol, cellobiose, erythritol, fucose, galactitol, glycerol, glycogen, inositol, inulin, 2-ketogluconate, 5 -ketogluconate, D-lyxose, mannitol, melezitose, $\alpha$-methylmannoside, L-rhamnose, L-sorbose, D-tagatose, trehalose, or xylitol. Acid production from gentiobiose and D-turanose is delayed. Acid production from amygdalin, arbutin, D-glucitol, gluconate, ribitol, and L-xylose varies with the strain. Esculin is hydrolyzed. The DNA G+C content is 48.0 to $48.3 \mathrm{~mol} \%$ (as determined by HPLC). Isolated from long-fermented rye sourdough.

The type strain is strain DSM 6035.

TABLE 4. 16S rDNA probe previously described for $L$. pontis and the corresponding binding sites in phylogenetically related species

\begin{tabular}{|c|c|}
\hline Probe or strain & Sequence \\
\hline L. pontis probe.. & GGTAATCCATCGTCAAATC $3^{\prime}$ \\
\hline 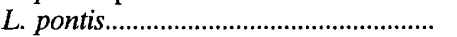 & GAUUUGACGAUGGAUUACC \\
\hline 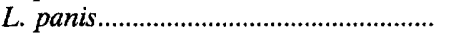 & GAUUUGACGAUGGAUUACC \\
\hline 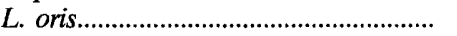 & GAUUUGACGUUGGAUUCCC \\
\hline 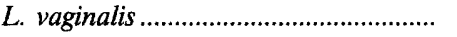 & GAUAUGACGUGCUUGCACU \\
\hline  & UGAUUGACGAUGGAUCACC \\
\hline
\end{tabular}

\section{ACKNOWLEDGMENTS}

We thank N. Weiss (DSMZ-Deutsche Sammlung von Mikroorganismen und Zellkulturen GmbH, Braunschweig, Germany), G. Auling (Universität Hannover, Hannover, Germany), and K. Komagata (Tokyo University of Agriculture, Tokyo, Japan) for their valuable advice and support.

This work was financed in part by Isernhäger Landkost Menge GmbH \& Co., Isernhagen, Germany, which also provided the sourdough.

\section{REFERENCES}

1. Blum, H., H. Beier, and H. J. Gross. 1987. Improved silver staining of plant proteins, RNA and DNA in polyacrylamide gels. Electrophoresis 8:93-99.

2. Collins, M. D., U. Rodrigues, C. Ash, M. Aguirre, J. A. E. Farrow, A. Martinez-Murcia, B. A. Phillips, A. M. Williams, and S. Wallbanks. 1991. Phylogenetic analysis of the genus Lactobacillus and related lactic acid bacteria as determined by reverse transcriptase sequencing of 16S rRNA. FEMS Microbiol. Lett. 77:5-12.

3. De Ley, J., H. Cattoir, and A. Reynaerts. 1970. The quantitative measurement of DNA hybridization from renaturation rates. Eur. J. Biochem. 12: 133-142.

4. De Soete, G. 1983. A least squares algorithm for fitting additive trees to proximity data. Psychometrica 48:612-626.

5. Embley, T. M., N. Faquir, W. Bossart, and M. D. Collins, 1989. Lactobacillus vaginalis sp. nov. from the human vagina. Int. J. Syst. Bacteriol. 39:368-370.

6. Farrow, J. A. E., and M. D. Collins. 1988. Lactobacillus oris sp. nov. from the human oral cavity. Int. J. Syst. Bacteriol. 38:116-118.

7. Gillis, M., J. De Ley, and M. de Cleene. 1970. The determination of molecular weight of bacterial genome DNA from renaturation rates. Eur. J. Biochem. 12:143-153.

8. Hammes, W. P., and R. F. Vogel. 1995. The genus Lactobacillus, p. 19-54. In B. J. B. Wood and W. Holzapfel (ed.), The lactic acid bacteria, vol. 2. The genera of lactic acid bacteria. Chapman \& Hall, Glasgow, United Kingdom.

9. Hammes, W. P., N. Weiss, and W. Holzapfel. 1992. The genera Lactobacillus and Carnobacterium, p. 1535-1594. In A. Balows, H. G. Trüper, M. Dworkin, W. Harder, and K. H. Schleifer (ed.), The prokaryotes, 2nd ed. Springer Verlag, New York.

10. Huss, V. A. R., H. Festl, and K. H. Schleifer. 1983. Studies on the spectrophotometric determination of DNA hybridization from renaturation rates. Syst. Appl. Microbiol. 4:184-192.

11. Jukes, T. H., and C. R. Cantor. 1969. Evolution of protein molecules, p. 21-132. In H. N. Munro (ed.), Mammalian protein metabolism. Academic Press, New York.

12. Kandler, O., and N. Weiss. 1986. Genus Lactobacillus, p. 1209-1234. In P. H. A. Sneath, N. S. Mair, M. E. Sharpe, and J. G. Holt (ed.), Bergey's manual of systematic bacteriology, vol. 2. The Williams and Wilkins Co., Baltimore.

13. Menge, W. January 1977 . Verfahren zur Herstellung eines natürlichen flüssigen Sauerteiges für die Bereitung von Brot und Backwaren. German patent $2,611,972$.

14. O'Sullivan, D. J., and T. R. Klaenhammer. 1993. Rapid mini-prep isolation of high-quality plasmid DNA from Lactococcus and Lactobacillus spp. Appl. Environ. Microbiol. 59:2730-2733.

15. Pot, B., W. Ludwig, K. Kersters, and K. H. Schleifer. 1994. Taxonomy of lactic acid bacteria, p. 13-89. In L. De Vuyst and E. J. Vandamme (ed.), Bacteriocins of lactic acid bacteria: genetics and applications. Chapman \& Hall, Glasgow, United Kingdom.

16. Rainey, F. A., M. Dorsch, H. W. Morgan, and E. Stackebrandt. 1992. 16S rDNA analysis of Spirochaeta thermophila: its phylogenetic position and implications for the systematics of the order Spirochaetales. Syst. Appl. Microbiol. 16:224-226.

17. Rainey, F. A., and E. Stackebrandt. 1993. 16S rDNA analysis reveals phylogenetic diversity among the polysaccharolytic clostridia. FEMS Microbiol. Lett. 113:125-128.

18. Spicher, G., and H. Stephan. 1993. Die Technik der Roggen-Sauerteigführung. Sauerteigführungen, p. 278-312. In Handbuch Sauerteig, 4th ed. Behr's Verlag, Hamburg, Germany.

19. Stackebrandt, E., and B. M. Goebel. 1994. Taxonomic note: a place for DNA-DNA reassociation and $16 \mathrm{~S}$ rRNA sequence analysis in the present species definition in bacteriology. Int. J. Syst. Bacteriol. 44:846-849.

20. Strohmar, W., and H. Diekmann. 1992. Die Mikrobiologie eines LangzeitSauerteiges. Z. Lebensm. Unters. Forsch. 194:536-540.

21. Sugihara, F. T. 1985 . Microbiology of breadmaking, p. 249-262. In B. J. B. Wood (ed.), Microbiology of fermented foods, vol. 1. Elsevier Applied Science Publishers, New York.

22. Takahashi, M. 1993. An improved method for DNA preparation from lactic acid bacteria resistant to lytic enzymes and its application to bacterial systematics. Ph. D. thesis. University of Agriculture, Tokyo.

23. Tamaoka, J., and K. Komagata. 1984. Determination of DNA base compo- 
sition by reversed-phase high performance liquid chromatography. FEMS Microbiol. Lett. 25:125-128.

24. Teuber, M. 1993. The genus Lactobacillus, p. 330-338. In H. J. Rehm and G. Reed (ed.), Biotechnology, vol. 1. Biological fundamentals. Verlag Chemie, New York.

25. Vogel, R. F., G. Böcker, P. Stolz, M. Ehrmann, D. Fanta, W. Ludwig, B. Pot, K. Kersters, K. H. Schleifer, and W. P. Hammes. 1994. Identification of lactobacilli from sourdough and description of Lactobacillus pontis sp. nov.
Int. J. Syst. Bacteriol. 44:223-229.

26. Wayne, L. G., D. J. Brenner, R. R. Colwell, P. A. D. Grimont, O. Kandler, M. I. Krichevsky, L. H. Moore, W. E. C. Moore, R. G. E. Murray, E. Stackebrandt, M. P. Starr, and H. G. Trüper. 1987. Report of the Ad Hoc Committee on Reconciliation of Approaches to Bacterial Systematics. Int. J. Syst. Bacteriol. 37:463-464.

27. Weiss, N., and U. Schillinger. 1984. Lactobacillus sanfrancisco sp. nov., nom. rev. Syst. Appl. Bacteriol. 4:507-511. 